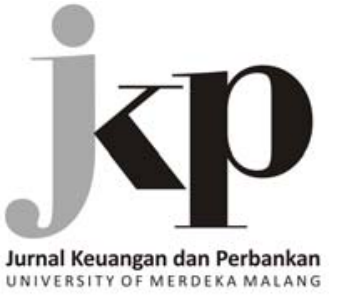

Article history:

Received: 2019-08-09

Revised: 2019-09-22

Accepted: 2019-10-16

\section{Keywords:}

Board of directors; Characteristics; Credit risk; Islamic banks; Non-performing financing

JEL Classification: G21, G32

\title{
Board of directors and credit risk: An empirical study of Indonesian Islamic banks
}

\author{
Peni Nugraheni ${ }^{1}$, Rifqi Muhammad ${ }^{2}$ \\ ${ }^{1}$ Department of Accounting, Faculty of Economics and Business, Universitas \\ Muhammadiyah Yogyakarta \\ Jl. Brawijaya, Yogyakarta, 55183, Indonesia \\ ${ }^{2}$ Department of Accounting, Faculty of Business and Economics, Universitas Islam Indonesia \\ Jl Ring Road Utara, Yogyakarta, 55283, Indonesia
}

\begin{abstract}
Credit risk is the primary risk in the banking industry related to its function in distributing credit to customers. Decreasing credit risk is the main duty of the management of banks. We examine the relationship between the Board of Directors (BOD) characteristics and credit risk in the Indonesian Islamic bank. BOD characteristics consist of BOD size, educational qualification, number of meetings, and expertise. The samples in this study are full-fledged Islamic banks in Indonesia that publish annual reports for the year 2013-2017. The data are processed using panel data regression. We indicate that the number of $\mathrm{BOD}$ meetings has a negative influence on credit risk, BOD size has a positive influence on credit risk while educational qualification and expertise do not influence credit risk of Islamic banks in Indonesia. Understanding BOD characteristics and credit risk are useful to mitigate the implementation of corporate governance for Islamic banks in the two-tier board system. The findings are expected to have a contribution to strengthening the BOD's role to encourage the better performance of Islamic banks.
\end{abstract}

\section{Abstrak}

Risiko kredit merupakan risiko utama dalam industri perbankan terkait dengan peran bank sebagai penyalur kredit kepada masyarakat. Mengurangi risiko kredit menjadi tugas utama manajemen bank. Kami menguji hubungan antara karakteristik dewan direksi (BOD) dan risiko kredit pada bank umum syariah di Indonesia. Karakteristik BOD terdiri dari ukuran $B O D$, kualifikasi pendidikan, jumlah rapat, dan keahlian. Sampel dalam penelitian ini adalah bank umum syariah di Indonesia yang mempublikasikan laporan tahunan tahun 2013-2017. Data dianalisis menggunakan regresi data panel. Kami menunjukkan bahwa jumlah rapat direksi memiliki pengaruh negatif pada risiko kredit, ukuran direksi berpengaruh positif pada risiko kredit sedangkan kualifikasi pendidikan dan keahlian tidak memengaruhi risiko kredit bank syariah di Indonesia. Memahami karakteristik BOD dan risiko kredit bermanfaat untuk memitigasi penerapan tata kelola di bank umum syariah. Penelitian ini diharapkan dapat berkontribusi dalam memperkuat peran BOD untuk mendorong kinerja bank syariah yang lebih baik.

How to Cite: Nugraheni, P., \& Muhammad, R. (2019). Board of directors and credit risk:
An empirical study of Indonesian Islamic banks. Jurnal Keuangan dan Perbankan,
23(4), 503-513. https:/ / doi.org/10.26905/jkdp.v23i4.3484

How to Cite: Nugraheni, P., \& Muhammad, R. (2019). Board of directors and credit risk:
An empirical study of Indonesian Islamic banks. Jurnal Keuangan dan Perbankan,
23(4), 503-513. https:/ / doi.org/10.26905/jkdp.v23i4.3484

How to Cite: Nugraheni, P., \& Muhammad, R. (2019). Board of directors and credit risk:
An empirical study of Indonesian Islamic banks. Jurnal Keuangan dan Perbankan,
23(4), 503-513. https:/ / doi.org/10.26905/jkdp.v23i4.3484

This is an open access

article under the CC-BY-SA license $\triangle$ Corresponding Author:

Rifqi Muhammad:

Tel +62 274898444

E-mail: rifqimuhammad@uii.ac.id

\section{(c) () (2)}




\section{Introduction}

Banks have several risks related to their main activities in channeling financing. The most important risk that must be faced in banking activities is credit risk (Elgari, 2003). Credit risk is related to the debtor's ability to pay on time. Credit risk in Islamic banks and conventional banks is often compared to assess their performance. Credit risk can be seen from the ratio of non-performing loans (NPL) in the conventional bank or non-performing financing (NPF) in the Islamic bank. Many factors influence the occurrence of credit risk in banks, including the types of contracts or financing agreements, weak corporate governance, poor risk management and moral hazard from the debtor itself (Mokni et al., 2014; Siswanti, 2016; Abobakr \& Elgiziry, 2017; Soekapdjo et al., 2018).

Credit risk is the main cause of financial instability in the banking industry (Ferhi, 2018). High credit risk that cannot be overcome by banks can reduce the bank's profits so that it affects the bank's profitability level (Firmansyah, 2014). In Indonesia, credit risks in conventional banks and Islamic banks have significant differences value between the two banks. During the past 4 years, NPF of Islamic banks amounted to $4.95 \%$ for the year $2014,4.84 \%$ in 2015 , $4.42 \%$ in 2016 and $4.76 \%$ in 2017, while the NPL value in conventional banks was $2.16 \%$ (2014), $2.49 \%$ (2015), $2.93 \%$ (2016) and 2.59\% (2017) (FSA, 2019). The comparison of the numbers can be seen in Figure 1.

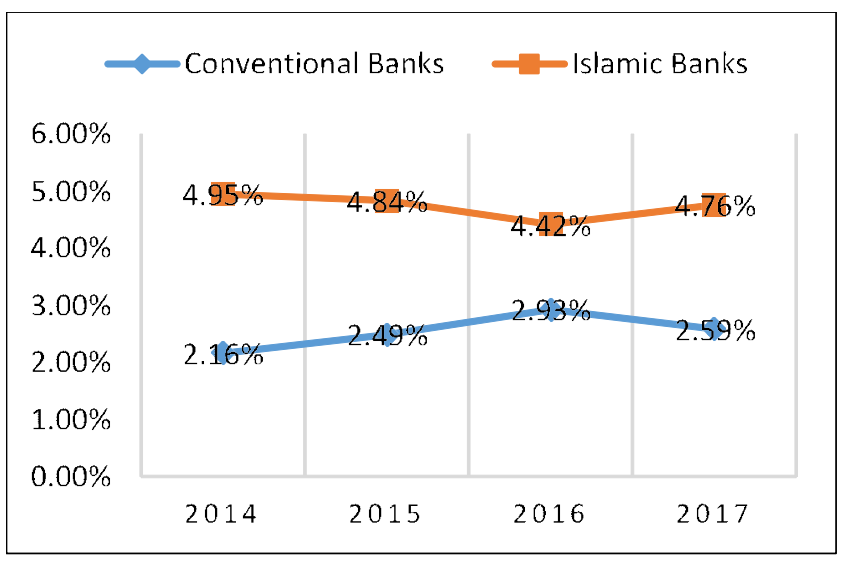

Figure 1. NPF and NPL of banks in Indonesia
Based on Figure 1, it appears that the NPF values of Islamic banks vary in the range of $4 \%$ to $5 \%$ but they are still higher than conventional banks. According to Ferhi (2018), additional credit risk may occur in Islamic banks because of the types of Islamic banking products. Further, Soekapdjo et al. (2018) state that the higher NPF of Indonesian Islamic banks because of the new operational experience of Islamic banks and the limited ability of employees in the financing distribution. Majdina, Munandar, \& Effendi (2019) state that Islamic banks may face potential losses due to high NPF and it can impact on the bad performance of Islamic banks. The performance of the bank to manage the NPF will influence the overall financial performance of Islamic banks.

For Islamic banks, credit risk is a challenge for the managers because they must be able to manage it according to Islamic principles (Husa \& Trinarningsih, 2015). The implementation of good corporate governance (CG) in the banking industry should improve the bank's performance. According to Ginena (2014), good governance will enhance the supervision system that is efficient and cost-effective for capital allocation by the manager. Iqbal, Haider, \& Khan (2015) state that corporate governance has a positive relationship with the financial performance of Islamic banks in Pakistan. Furthermore, the success of the implementation of corporate governance in Islamic banks needs supporting facilities such as internal control, risk management, and prudent regulation and supervision (Budiman, 2016).

Financing in Islamic banks needs effective risk management (Sundarajan \& Erico, 2002; Abedifar, Molyneux, \& Tarazi, 2013). The role of management then becomes very important for managing credit risk. The board of directors has duties and responsibilities to manage the bank's activities and increase bank efficiency to achieve the expected financial performance (McNulty, Florackis, \& Ormrod, 2012). The research about the role of the board of directors (BOD) as part of CG which has the authority to take actions that can directly affect the NPF has not 
been done so much. Therefore, the extent to which the BOD profile influences NPF in Islamic banks is interesting to study. Research on NPF is very interesting because the level of credit risk will affect how well the bank's performance level (Siswanti, 2016) and reflect the financing quality of the financing portfolio of banks and the banking industry in a country (Ozili, 2019).

Managing the NPF rate in Islamic banks needs special attention because they involve the ability to compete with conventional banks. The determinant factors on credit risk in the banking industry have been carried out by several studies. However, research on factors that influence NPF in Islamic banks in Indonesia is widely reviewed in terms of macro and microeconomic factors such as studies by Firmansyah (2014), Sukmana (2015) and Soekapdjo et al. (2018). This study fulfilled the gap in NPF research to focus on the corporate governance structure of Islamic banking by examining the effect of BOD characteristics on NPF rates in Islamic banks in Indonesia. Indonesia separates the function of management and supervision by different boards called the two-tier board. BOD has the responsibility to manage the operational activities of the company while the board of commissioners has the function to supervise and provide advice to the management. The characteristics of BOD may affect their performance in managing the risks of Islamic banks. BOD characteristics in this study include BOD size, educational qualifications, number of meetings, and expertise (Belkhir, 2009; Berger, Kick \& Schaeck, 2014; Darmadi, 2013; Fakhrunnas \& Ramly, 2017; Gafoor, Mariappan, \& Thyagarajan, 2018). Ozili (2019) states the importance of discussing the factors affecting credit risk is to manage risk in banks and maintain financial stability.

\section{Hypotheses Development}

Banking as an intermediary institution has the main role of raising funds from parties who are excess funds and channeling it to those who need funds. Some types of financing that can be distributed by Islamic banks such as profit and loss sharing (mudharaba and musharaka), mark-up financing (murabaha, salam, and istishna) and lease-based financing (ijara and ijara muntahiya bi tamlek). Generally, banks will face many risks related to the activities carried out such as credit risk, market risk, liquidity risk, and operational risk. Credit risk is defined as "the loss of income arising as a result of the counterparty's delay in payment on time or in full as contractually agreed" (Ahmed \& Khan, 2005).

According to Safiullah \& Shamsuddin (2017), the different types of financing will impact on the different credit risk. Profit and loss sharing (PLS) financing has a higher credit risk compared to other types of financing due to the moral hazard of borrowers who have incentives to share the loss with banks (El-Hawary, Grais, \& Iqbal, 2007). Therefore, PLS financing can influence the profitability of Islamic banks (Risfandy, 2018)

The previous study conducted by Ahmed \& Khan (2005) also states that profit and loss sharing (PLS) modes of financing and mark-up financing (salam and istishna) are riskier than murabahah, and ijarah. Therefore, PLS financing usually has smaller amount than murabahah, financing. Figure 2 below shows the proportion of financing in Islamic banks in Indonesia for the year of 2017 based on their contracts (FSA, 2019).

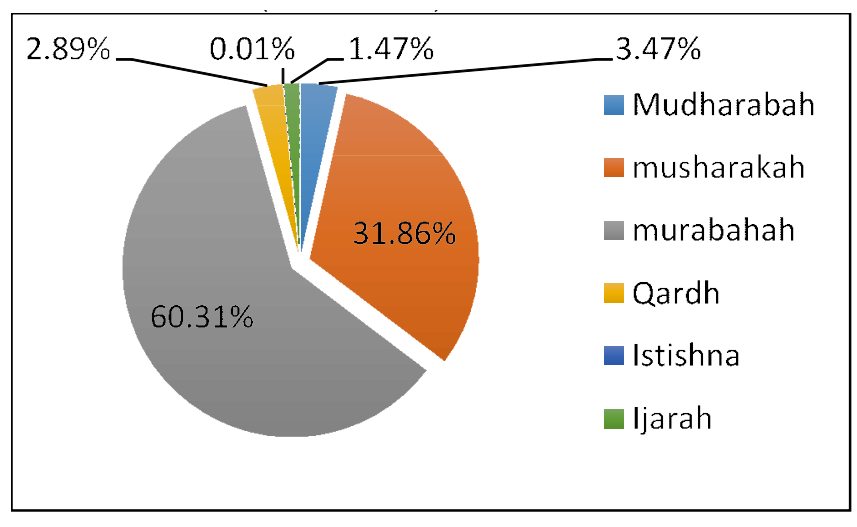

Figure 2. The proportion of financing in Islamic banks 
Figure 2 shows that murabahah dominates the financing distributed by Islamic banks with $60.32 \%$, followed by musharakah (31.86\%) and mudharabah (3.47\%). According to Abusharbeh (2014), Indonesian Islamic banks have a low level of profit and loss sharing financing to avoid credit risk and therefore, Islamic banks prefer murabahah financing to increase the profitability and ensure the high liquidity. Ernawati (2016) states that although mudharabah is attractive financing that offering high returns, Islamic banks in Indonesia tend to reluctant to manage this financing because of its high risk and prudential reason. Therefore, Islamic banks apply musharakah as alternative financing although it produces lower potential revenue (Ernawati, 2016).

Credit risks in those contracts are in the form of the inability of the debtor to fulfill the obligation to the bank on the maturity dates and it will have an impact on the loss of Islamic banks (Al-Wesabi \& Ahmad, 2013). According to Majdina, Munandar, \& Effendi (2019), Islamic banks should manage the strategy of funds' distribution to improve their performance. Mokni et al. (2014) who summarize some previous studies about the types of risks that dominate the banking industry, state that the ability to analyze credit risk will affect the ability of the Islamic bank to manage risk efficiently.

Indonesia adopts two-tier boards which means there is a separation of positions between the managing company (management/board of directors) and the supervising company (board of commissioners). Law number 21 the year 2008 about Islamic Banking states that the directors are fully responsible for the implementation of Islamic bank management based on prudential principles and sharia principles. Risk management becomes one of the responsibilities of BOD.

Several empirical studies have examined the relationship between BOD and credit risk. Fakhrunnas \& Ramly (2017) investigate 24 Islamic banks in Southeast Asia for the year 2009 to 2014 and find that independent directors and board sizes have a positive effect on credit risk. A study con- ducted by McNulty, Florackis, \& Ormrod (2012) analyse the characteristics of the BOD consisting of three factors, (1) structural characteristics involving board size and composition, (2) director-specific characteristics including pay, tenure and experience and (3) board process such as behavior to do with effort norms on boards, interaction between directors and use of knowledge and skill. Using questionnaire surveys to board chairs at the 1.000 largest companies in the United Kingdom, they find that board size, remuneration, tenure, effort norm, and cognitive conflict are significant in determining the financial risk level. The other study by Bourakba \& Zerargui (2015) examines governance factors affecting the credit risk of Islamic banks in GCC during the period 2005-2012. Their finding shows that the composition and the size of BOD, board committees, ownership concentration and size of the sharia supervisory board have negative relationship on the non-performing financing.

According to Safiullah \& Shamsuddin (2017), board size establishes the capability of the board to work in carrying out its function. BOD size can affect the effectiveness of decisions made by the board. Financing distribution requires intensive supervision to ensure regular payment by debtors and avoid credit risk. Larger the member of the board increases the capacity for monitoring (Farook, Hassan, \& Lanis, 2011), including controlling credit risk and thus reducing NPF. McNulty, Florackis, \& Ormrod (2012) find that board size influences the effective performance of risk management while Bourakba \& Zerargui (2015) find the board size has a negative effect on the credit risk of Islamic banks in GCC. Therefore, the hypothesis of this study is:

$H_{1}$ : $\quad$ BOD size negatively influences the credit risk of Islamic banks in Indonesia

The prior studies indicate that the educational qualification of the board is a tool to improve corporate governance (Berger, Kick \& Schaeck, 2014). According to Darmadi (2013), it is important to ex- 
amine the education of CEO and board members toward firm performance to ensure the level of supervisory of the board. Credit risk of financial contracts needs to be controlled because of the enormous impact on the performance of Islamic banks. Bank requires the right strategy to manage this risk and therefore, BOD needs to have adequate knowledge in regulating the procedures and policies of credit risk control. The higher the educational level of BOD members, the higher the capability of the member to handle the NPF level and thus reducing credit risk. Berger, Kick \& Schaeck (2014) state that the education of board, in terms of Ph.D. degrees, will reduce the risk because the board can apply better risk management techniques. Thus, the hypothesis of the study is derived as:

$\mathrm{H}_{2}$ : educational qualification of BOD members negatively influences the credit risk of Islamic banks in Indonesia

Every policy and a strategic decision must be decided through a board of directors meeting. Related to the risk management, $\mathrm{BOD}$ is responsible to formulate and determine the policy and risk exposure taken by the banks. NPF becomes a crucial financial ratio in the banking sector and how to handle it will always be an intensive discussion. According to Naseem et al. (2017), a large number of board meetings can handle the business operation of the organization. Furthermore, the more often the BOD organizes meetings, the risk of credit will be more intensively monitored and thus the NPF is expected to be controlled. Iqbal, Haider, \& Khan (2015) find that the number of meeting boards has a positive significant effect on the financial performance (Return on Assets/ROA) of Islamic banks in Pakistan. Gafoor, Mariappan, \& Thyagarajan (2018) also find a similar result between board meetings and bank performance (ROA) in India. Based on the explanation above, the hypothesis in this study are:

$H_{3}$ : number of BOD meeting negatively influences credit risk of Islamic banks in Indonesia
Profit and loss sharing (PLS) financing such as musharaka and mudharaba are riskier than other types of financing. Islamic banks will bear all the losses in the event of business failure. Related to this risk, Ramly \& Nordin (2018) state that Islamic banks can maintain sustainability if it can identify the risk. Further, they argue that relevant expertise in the field of sharia and banking can contribute to practical issues related to banking operation. Gafoor, Mariappan, \& Thyagarajan (2018) state that large numbers of financial experts on the board are important for improving the performance of the bank. The expertise will guide effectively in the business decision making made by the board, especially in terms of the mechanism of distributing and supervising financing. The mechanism is expected to reduce the credit risk on the bank. Therefore, the hypothesis of this study is:

$H_{4}$ : expertise of BOD members negatively influences the credit risk of Islamic banks in Indonesia

\section{Method, Data, and Analysis}

This study is a quantitative study to find the influence of BOD characteristics on credit risk in Indonesian Islamic banks. The samples are 12 fullfledged Islamic banks and data source comes for annual reports published by the banks during 20132017. The study employs analysis data of panel data regression using E-views.

The dependent variable used in this study is non-performing financing (NPF) which is measured by bad financing outstanding divided by total financing outstanding. For independent variables, this study focuses on BOD characteristics, namely BOD size, educational qualifications, number of meetings, and expertise. Board size is measured by the number of BOD members. Educational qualification (education) is measured by the average of total score from the classification of score 1 for those who have undergraduate degrees, score 2 for master's degrees and score 3 for doctoral degrees. The board 
meeting is measured by the number of BOD meeting in one year. Board expertise is measured by the percentage of BOD members with business/finance knowledge. The study proposes the estimation model to examine the influence of BOD characteristics and credit risk in Islamic banking as follows:

$$
\begin{aligned}
\text { NPF }= & \alpha+\beta_{1} \text { Size }+\beta_{2} \text { Education }+\beta_{3} \text { Meeting }+ \\
& \beta_{4} \text { Expertise }+\varepsilon
\end{aligned}
$$

Where: NPF $=$ credit risk (non-performing financing); $\alpha=$ intercept; $\beta=$ slope; Size= number of BOD member; Education = educational qualification of BOD; Meeting= number of BOD meeting; Expertise $=$ expertise of BOD member; $\varepsilon=$ error term

\section{Results}

This study uses the annual report of 12 fullfledged Islamic banks in Indonesia from the year 2013-2017. The data that can be accessed by the study are 59 data. The paper utilizes the random effect model to analyze the empirical evidence on credit risk in Indonesian Islamic banks. The descriptive statistical results are shown in Table 1.

Based on Table 1, NPF has a mean value of 5.541186 , a maximum value of 43.99 and a minimum value of 0 . The mean of NPF value $(5.54 \%)$ is slightly above the requirement of the Indonesian central bank (Bank Indonesia) of 5\%. The highest NPF value of $43.99 \%$ is experienced by Islamic bank namely Maybank Syariah in the year 2016 which is in that year the bank suffered a net loss of IDR 163.74 billion. What is interesting is that Maybank Syariah was able to manage NPF to $0 \%$ in 2017 and recorded a profit of IDR 71.49 billion. In the annual report of 2017, the management of Maybank Syariah stated that the strategy taken was "..... to be more prudence in building assets and putting more focus and efforts on managing NPF accounts to ensure maximum recovery either through restructuring, rescheduling or assets acquisition".

Table 1 indicates that board size has a mean value of 4.440, maximum and minimum values are 8 and 3 members. The board size is in accordance with the regulation of the Financial Service Authority of Indonesia that banks must have at least 3 (three) members of BOD. The mean value of the educational qualification of board members is 1.615 , with maximum value is 2.25 and the minimum value is 1 . The highest score of 2.25 is achieved by Islamic banks namely BNI Syariah with two directors holding a Ph.D. degree from a total of four directors, while the score 1 as the lowest score is obtained by Islamic banks whose directors do not have a postgraduate degree.

The number of BOD meetings has a mean value of 31.661, a maximum value is 108 and a minimum value is 6 . The regulation does not specify provisions regarding the number of meetings that must be held by the director, and only states that each strategic policy and decision must be decided through the board of directors' meeting. The last variable is the expertise variable that has a mean value of 0.737 and maximum and minimum values are 1 and 0 . The value of 1 indicates that Islamic banks have BOD which all members have expertise in the field of economics or finance.

Table 1. Descriptive statistics

\begin{tabular}{lrrrr}
\hline Variables & Mean & Maximum & Minimum & Std. Dev \\
\hline NPF & 5.541 & 43.990 & 0.000 & 7.550 \\
Size & 4.440 & 8.000 & 3.000 & 1.249 \\
Education & 1.615 & 2.250 & 1.000 & 0.318 \\
Meeting & 31.661 & 108.000 & 6.000 & 17.60 \\
Expertise & 0.737 & 1.000 & 0.000 & 0.225 \\
\hline
\end{tabular}


However, the data do not have normal distribution indicated by the value of Jarque-Bera of 4.745 and the probability of $0.00<$ alpha 0.05 . Therefore, all data are converted into logarithm and the result shows that the data is normally distributed (Jarque-Bera is 2.442 and probability value is 0.294 $>0.05)$.

The panel data regression used in this study is the random effect model. Table 2 shows that the value of r-squared is 0.260 and it means that dependent variables (credit risk/NPF) can be explained by independent variables in the amount of $26.08 \%$ and the rest of $73.92 \%$ can be explained by other factors not included in this study. The regression result of the F-test has a significant value of 0.003 which is lower than the alpha value of $0.05(0.003<$ $0.05)$ and indicates that BOD characteristics which consist of size, educational qualification, number of meeting and expertise influence NPF of Islamic banks in Indonesia.

\section{Discussion}

The relationship of each BOD characteristics and credit risk is the result of the t-test and can be described below. First, hypothesis 1 examines the relationship between BOD size and credit risk. The result indicates that $\mathrm{BOD}$ size influences credit risk positively in Islamic banks. The higher member of BOD will encourage the higher level of Islamic banks and therefore, $\mathrm{H}_{1}$ is rejected.
BOD size refers to the number of directors on the board. All Islamic banks have fulfilled the regulation of Bank Indonesia to have minimum of three directors. However, the complexity of banking operations needs quality monitoring and decision making (Ferrero-Ferrero, Fernández-Izquierdo, \& Muñoz-Torres, 2012). Chapra \& Ahmed (2002) state that the important issues related to BOD are ensuring a good management team and oversight of management. The issues associated with the responsibilities of BOD in CG are to set overall policy and strategy for the corporation. The BOD's performance will determine the effectiveness of those policies and strategies. The management techniques of monitoring and controlling will influence the application of PLS financing (Muhammad, 2014). When the member of BOD has weak monitoring and controlling, they will have difficulty in managing the financing and therefore the credit risk may have a high level.

For the second hypothesis, this study examines the effect of educational qualification toward NPF and the statistical result shows that education has no effect on NPF in Islamic banks. According to Darmadi (2013), some factors must be considered when measuring the management quality, such as the experiences and network. Experience can increase the knowledge of the board in addition to the knowledge from formal education (Darmadi, 2013). The result of this study is similar with Darmadi (2013) who finds that postgraduate degree of BOD mem-

Table 2. Result of panel data regression

\begin{tabular}{lccrr}
\hline \multicolumn{1}{c}{ Variables } & Coefficient & Std. Error & t-Statistic & Prob. \\
\hline C & 2.529 & 1.216 & 2.079 & 0.042 \\
LogSize & 1.145 & 0.607 & 1.884 & $0.065^{*}$ \\
LogEdu & 0.436 & 0.830 & 0.525 & 0.601 \\
LogMeet & -0.938 & 0.227 & -4.126 & $0.000^{* *}$ \\
LogExp & 0.326 & 0.451 & 0.722 & 0.473 \\
\hline R-Squared & 0.260 & & F Statistic & 4.586 \\
Adjusted R-Squared & 0.203 & Prob. (F-Statistic) & 0.003 \\
\hline
\end{tabular}

* Significant at the level of $0.10, * *$ significant at the level of 0.05 
bers in 160 company listed in Indonesian Stock Exchange has no significant relationship with financial performance and Abobakr \& Elgiziry (2017) who state that education of board member has an insignificant relationship with credit risk.

For a board meeting, the result indicates that board meeting has a negative influence on the NPF of Islamic banks and thus $\mathrm{H}_{3}$ is accepted. The statistical result provides evidence that Islamic banks with less frequent board meetings have higher NPF. Mismanagement of credit risk will impact the performance of the bank and therefore the board of directors should discuss intensively and regularly to manage the risk. The negative relation between a board meeting and credit risk is consistent with the study by Iqbal, Haider, \& Khan (2015) and Gafoor, Mariappan, \& Thyagarajan (2018) who find that the number of meeting boards has a positive significant effect on the ROA of Islamic banks.

Board expertise has implied that an Islamic bank with a large or small number of economic/ finance expertise in the board does not affect credit risk. Therefore, $\mathrm{H}_{4}$ is rejected. It is a surprising result because the mean value of this variable is $74.35 \%$ indicating that mostly the BOD members have financial expertise. The result can be understood when we see the result of $\mathrm{H}_{2}$ that education also does not influence the credit risk in Islamic banks. The finding is contrary to the hypothesis but in line with the result of McNulty, Florackis, \& Ormrod (2012) who do not find the relationship between board expertise and risk. The skill of the board members may be increasing along with the experience of a long managerial position to manage the company's operation (Darmadi, 2013). Kusumastuti et al. (2007) find that the economic and finance background of the board of directors has no influence on company value in Indonesian companies. There is a possibility that the expertise of board members following the type of business of the company is more necessary because it can support the continuity of the company's business. In addition, there is a need for soft skills in running a business which different from expertise from formal education or hard skill (Kusumastuti et al., 2007).

\section{Robustness test}

This study uses a random effect model to test the hypotheses. To provide more evidence, a robustness test is conducted to check the previous result through two additional analyses. The study runs the other methods of panel data regression using pooled regression (a) and the fixed effect model (b). The result is shown in Table 3.

Based on Table 3, the results of pooled regression (column a) show the similar results that board size has a positive influence and board meeting has a negative influence to the credit risk. For the fixed effect model (column b), board meeting also has a negative influence on the credit risk. However, this study still should rely on the result of the random effect model above.

Table 3. The Robustness Test

\begin{tabular}{lcccc}
\hline \multicolumn{1}{c}{ Variable } & Coefficient (a) & Prob. (a) & Coefficient (b) & Prob. (b) \\
\hline C & 3.162 & 0.001 & 2.832 & 0.123 \\
logsize & 1.975 & $0.000^{* *}$ & 0.183 & 0.844 \\
LogEdu & -0.549 & 0.447 & 1.553 & 0.148 \\
LogMeet & -1.292 & $0.000^{* *}$ & -0.804 & $0.004^{* *}$ \\
LogExp & 0.942 & $0.045^{* *}$ & -0.101 & 0.843 \\
R-squared & 0.682 & 0.767 & & 0.447 \\
\hline
\end{tabular}

* Significant at the level of $0.10,{ }^{* *}$ significant at the level of 0.05 


\section{Board of Directors and credit risk: An empirical study of Indonesian Islamic banks}

Peni Nugraheni, Rifai Muhammad

\section{Conclusion, Limitations, and Suggestions Conclusion}

Credit risk of Islamic banks must be managed well because it is one of the determinants of bank performance to be able to exist continuously and compete with conventional banks. The role of the board of directors who has the responsibility to manage the bank activities will influence the condition of the credit risk that occurs. This study aims to examine the relationship between BOD characteristics and credit risk in Indonesian Islamic banks. The results show that BOD size has a positive influence on credit risk, numbers of BOD meetings have a negative influence on credit risk, while educational qualification and expertise have an insignificant influence on credit risk in Islamic banks in Indonesia.

However, there are external factors that influence NPF such as economic growth, inflation rate, and exchange rate and those factors can not be handled by management. Therefore, the banks should strengthen their internal management to reduce the possibility of default by the debtors by improving efficiency and prudence in decision making, including in risk management. The establishment of a risk governance structure will help BOD in monitoring the implementation of effective risk management.
The findings imply the parties related to risk management of the bank. Islamic banks can identify which characteristics of BOD that influence credit risk to be adjusted with the need of the banks. For the regulators, this study may improve the regulation about the structure of corporate governance, especially the BOD in managing credit risk to keep the sustainability of the banks. Understanding BOD characteristics and credit risk are useful to mitigate the implementation of corporate governance for Islamic banks in the two-tier board system. Finally, the findings are expected to have a contribution to strengthening the BOD's role to encourage the better performance of Islamic banks.

\section{Limitation and suggestions}

There are several limitations to this study. The study only focuses on examining the four characteristics of BOD. For the future study, the other characteristics such as gender, experience, remuneration, and other diversity of the board can be included to give comprehensive characteristics of BOD. Furthermore, BOD is only one of the corporate governance structure. The other boards in CG such as the board of commissioners (in the two-tier board mechanism) and sharia supervisory board may also have a contribution to managing credit risk in Islamic banks.

\section{References}

Abedifar, P., Molyneux, P., \& Tarazi, A. (2013). Risk in Islamic banking. Review of Finance, 17(6), 20352096. https://doi.org/10.1093/rof/rfs041

Abobakr, M. G., \& Elgiziry, K. (2017). The relationship between board of directors' characteristics and bank risk-taking: Evidence from Egyptian banking sector. Journal of Finance and Accounting, 5(1), $24-33$. https://doi.org/10.11648/j.jfa.20170501.13

Abusharbeh, M. T. (2014). Credit risks and profitability of Islamic banks: Evidence from Indonesia. World Review of Business Research, 4(3), 136-147.

Ahmed, H., \& Khan, T. (2005). Risk management in Islamic banking. Handbook of Islamic Banking, 144158. 


\section{Jurnal Keuangan dan Perbankan}

Volume 23, Issue 4, October 2019: 503-513

Al-Wesabi, H. A. H., \& Ahmad, N. H. (2013). Credit risk of Islamic banks in GCC countries. International Journal of Banking and Finance, 10(2), 1-19.

Belkhir, M. (2009). Board of directors' size and performance in the banking industry. International Journal of Managerial Finance, 5(2), 201-221. https://doi.org/10.1108/17439130910947903

Berger, A. N., Kick, T., \& Schaeck, K. (2014). Executive board composition and bank risk taking. Journal of Corporate Finance, 28(3), 48-65. https://doi.org/10.1016/j.jcorpfin.2013.11.006

Bourakba, C., \& Zerargui, H. (2015). The relationship between credit risk and corporate governance in Islamic banking: An empirical study. Issues in Business Management and Economics, 3(4), 67-73.

Budiman, F. (2016). Pengaruh kualitas penerapan Good Corporate Governance ( GCG ) terhadap tingkat pengembalian dan risiko pembiayaan bank syariah di Indonesia. Muqtasid, 7(2), 1-21. https://doi.org/10.18326/muqtasid.v7i2.1-21

Chapra, M. U., \& Ahmed, H. (2002). Corporate governance in Islamic financial institutions. Working Paper 6. September. Islamic Development Bank, Islamic Research and Training Institute.

Darmadi, S. (2013). Board members' education and firm performance: Evidence from a developing economy. International Journal of Commerce and Management, 23(2), 113-135. https://doi.org/10.1108/10569211311324911

El-Hawary, D., Grais, W., \& Iqbal, Z. (2007). Diversity in the regulation of Islamic financial institutions. The Quarterly Review of Economics and Finance, 46(5), 778-800. https://doi.org/10.1016/j.qref.2006.08.010

Elgari, M. A. L. I. (2003). Credit risk in Islamic banking and finance. Islamic Economic Studies, 10(2), 1-25.

Ernawati. (2016). Risk of profit loss sharing financing: The case of Indonesia. Al-Iqtishad: Journal Ilmu Ekonomi Syariah, 8(1), 101-116. https://doi.org/10.15408/aiq.v8i1.2511

Fakhrunnas, F., \& Ramly, Z. (2017). Board of directors and risk-taking behavior of Islamic banks in South East Asia. Tazkia Islamic Finance and Business Review, 10(2), 162-177. https://doi.org/10.30993/tifbr.v10i2.107

Farook, S., Hassan, M. K., \& Lanis, R. (2011). Determinants of corporate social responsibility disclosure: The case of Islamic banks. Journal of Islamic Accounting and Business Research, 2(2), 114-141. https://doi.org/10.1108/17590811111170539

Ferhi, A. (2018). Credit risk and banking stability/ : A comparative study between Islamic and conventional banks. International Journal of Law and Management, 60(4), 1009-1019. https://doi.org/10.1108/IJLMA-05-2017-0112

Ferrero-Ferrero, I., Fernández-Izquierdo, M. Á., \& Muñoz-Torres, M. J. (2012). The impact of the board of directors characteristics on corporate performance and risk-taking before and during the global financial crisis. Review of Managerial Science, 6(3), 207-226. https://doi.org/10.1007/s11846-012-0085-x

FSA. (2019). Sharia Banking Statistics. Financial Service Authority. Indonesia.

Firmansyah, I. (2014). Determinant of non-performing loan: The case of Islamic Bank Indonesia. Buletin Ekonomi Moneter dan Perbankan, 17(2), 241-268. https://doi.org/10.21098/bemp.v17i2.51

Gafoor, C. P. A., Mariappan, V., \& Thyagarajan, S. (2018). Board characteristics and bank performance in India. IIMB Management Review, 30(2), 160-167. https://doi.org/10.1016/j.iimb.2018.01.007

Ginena, K. (2014). Sharýah risk and corporate governance of Islamic banks. Corporate Governance, 14(1), 86-103. https://doi.org/10.1108/CG-03-2013-0038 


\section{Board of Directors and credit risk: An empirical study of Indonesian Islamic banks}

Peni Nugraheni, Rifqi Muhammad

Husa, P. P., \& Trinarningsih, W. (2015). Credit risk in Indonesia: Islamic bank vs conventional bank. Fokus Manajerial, 13(1), 53-60.

Iqbal, N., Haider, N., \& Khan, N. (2015). Impact of corporate governance on firm financial performance in Islamic financial institution. International Letters of Social and Humanistic Sciences, 51, 106-110. https://doi.org/10.18052/ www.scipress.com/ILSHS.51.106

Kusumastuti, S., Supatmi, \& Sastra, P. (2007). Pengaruh board diversity terhadap nilai perusahaan dalam perspektif corporate governance. Jurnal Akuntansi dan Keuangan, 9(2), 88-98.

Law of the Republic of Indonesia Number 21. (2008). Islamic Banking.

Majdina, N., Munandar, J. M., \& Effendi, J. (2019). The determinant factors of efficiency on Islamic banking and conventional banking in Indonesia. Jurnal Keuangan dan Perbankan, 23(3), 454-468. https://doi.org/10.26905/jkdp.v23i3.3157

McNulty, T., Florackis, C., \& Ormrod, P. (2012). Corporate governance and risk: A study of board structure and process. Research Report 129. Association of Chartered Certified Accountants. London.

Mokni, R. B. S., Echchabi, A., Azouzi, D., \& Rachdi, H. (2014). Risk management tools practiced in Islamic banks/†: Evidence in MENA Region. Journal of Islamic Accounting and Business Research, 5(1), 7797. https://doi.org/10.1108/JIABR-10-2012-0070

Muhammad, A. M. (2014). Critical analysis of some of the major internal hindrance factors in the application of musharakah financing by the Islamic banks. International Journal of Education and Research, 2(9), $125-142$.

Naseem, M. A., Riaz, S., Rehman, R. U., Ikram, A., \& Malik, F. (2017). Impact of board characteristics on corporate social responsibility disclosure. Journal of Applied Business Research, 33(4), 801-810. https://doi.org/10.19030/jabr.v33i4.10001

Ozili, P. K. (2019). Non-performing loans and financial development: New evidence. The Journal of Risk Finance, 20(1), 59-81. https://doi.org/10.1108/JRF-07-2017-0112

Ramly, Z., \& Nordin, N. D. H. M. (2018). Sharia supervision board, board independence, risk committee, and risk-taking of Islamic banks in Malaysia. International Journal of Economics and Financial Issues, 8(4), 290-300.

Risfandy, T. (2018). Equity financing and Islamic banks' profitability: Evidence from the biggest muslim country. Jurnal Keuangan dan Perbankan, 22(3), 496-505. https://doi.org/10.26905/jkdp.v22i3.2150

Safiullah, M., \& Shamsuddin, A. (2017). Risk in Islamic banking and corporate governance. Pacific-Basin Finance Journal, 47, 129-149. https://doi.org/10.1016/j.pacfin.2017.12.008

Siswanti, I. (2016). Implementasi good corporate governance pada kinerja bank syariah. Akuntansi Multiparadagma, 7(2), 307-321. https://doi.org/10.18202/jamal.2016.08.7023

Soekapdjo, S., Nugroho, L., Badawi, A., \& Utami, W. (2018). Bad debt issues in Islamic bank: Macro and micro influencing (Indonesia cases). International Journal of Commerce and Finance, 4(1), 10-26.

Sukmana, R. (2015). Determinants of non-performing financing in Indonesian Islamic banks. Working Paper Series 1436-03. Islamic Research and Training Institute (IRTI)

Sundarajan, V., \& Erico, L. (2002). Islamic Financial institutions and products in the global financial system: Key issues in risk management and challenges ahead. IMF Working Paper, WP/02/192. 